\title{
RIGHTS IN CRISIS
}

\section{KRZYSZTOF JASKUŁOWSKI, THE EVERYDAY \\ POLITICS OF MIGRATION CRISIS IN POLAND: BETWEEN NATIONALISM, FEAR AND EMPATHY}

Dominika Michalak

University of Warsaw

Krzysztof Jaskułowski’s The Everyday Politics of Migration Crisis in Poland: Between Nationalism, Fear and Empathy, published by Palgrave Macmillan, appeared at the beginning of 2019. The book is the first extensive qualitative study of Poles' attitudes towards the so-called migration crisis. As the work addresses one of the greatest political questions of recent years, it will likely have a wide impact on the scholarly debate on prejudices and Polish identity.

Jaskułowski writes of a "so-called" migration crisis because he does not agree with the label of crisis for the political events and decisions that have shaped the European Union's (EU) and Poland's current migration policies. He is interested in the years 2015-2016, when a record number of migrants from the Middle East and North Africa arrived in the EU to seek shelter from persecution, war, or poverty. In the European public debate, the term "crisis" began to be used. According to Jaskułowski, the term was not neutral as it came to define the extent of Europe's obligations towards the migrants, including the group most dependent on the EU's sense of solidarity, the refugees. Violation of the migrants' rights and limition of the aid afforded them was justified in a discourse framed in terms of a crisis. Supporters of the idea that the situation was extraordinary seemed to 
be saying that "Normally we would not tolerate such an approach but the conditions are truly exceptional." In the case of Poland, as Jaskułowski reminds us, solidarity towards migrants appearing on the EU's southern borders was defined very narrowly. In the end, Poland did not admit a single refugee under the relocation agreements, obscurely justifying its decision on security grounds (Jaskułowski 2019: 38).

Jaskułowski's precise opinion on EU or Polish policy towards the migrants during the period analysed is not entirely clear as this is not what the book is about. It is certain, however, that he considers solidarity with the migrants, and especially with the refugees, to be an ethical imperative as well as an obligation under EU law. When he proposes, in the third chapter, that the "migration crisis" should be considered first of all in terms of a crisis of refugees' rights, it becomes quite clear that we are dealing with a socially engaged work, though it lacks the least hint of anarchism (47-48). The author does not protest the existence of national boundaries or the procedure for granting international protection, but simply points to the discrepancy between the values enshrined in the law and their practical implementation. The traditional liberal belief in the individual is also reflected in the book's criticism of prejudice, in which Jaskułowski includes both the security discourse and Islamophobia. Both contribute to the curtailment of individual rights in the name of imagined threats and to treating refugees as victims, which encourages overprotective solidarity with them and deprives them of subjectivity $(105-110,132)$. The Everyday Politics of Migration Crisis in Poland can therefore be read as a story about how we think and speak of members of our European political community - people who are not EU citizens, but are certainly participants in our collective life, with certain rights and political subjectivity.

Jaskułowski devotes most attention to the years 2015-2016. This period, when the greatest number of migrants seeking international protection reached the EU and the public debate on the subject became particularly high-pitched, provides an ideal opportunity for studying the attitudes of Europeans. The topic was especially new for Poles, among whom different camps began to form in order to produce positions and rhetorical tools. By defining their obligations towards migrants coming to Europe from the Middle East and North Africa, they mobilised knowledge and imaginings shaped over decades in which emigration prevailed over immigration and the rhetoric of cultural unity among Polish citizens was dominant in the public discourse. Thus, Jaskułowski’s main question, concerning the relation between national identity and attitudes to migrants, is apt. 
Attitudes can be examined in many ways. A survey is most often used for this purpose. Jaskułowski relies on qualitative methods, however, and looks at two axes around which public opinion is shaped: the more influential participants in the debate (i.e., politicians and selected figures of popular culture) and ordinary people, the addressees of the public message, who not being devoid of their own opinions and polemic enthusiasms, place that message in the context of their proper experience and emotional tendencies. In the book we find an analysis of selected public pronouncements and a report on a qualitative study composed of 191 structured individual interviews and 2 focus group interviews. While the empirical material is enormous, it does not ensure the study's representativeness for all of Poland.

The issue here is not one of representativeness in the statistical sense which is not expected of qualitative research and to which Jaskułowski himself makes not the smallest claim - but about capturing the greatest possible variety of attitudes with their socio-cultural sources. Jaskułowski conducted his research in Lower Silesia and the Opole region, both in the largest towns and in smaller localities. He included areas that have experienced economic degradation in recent times and those where the situation was clearly better. Among the respondents were poor and well-to-do people, people with and without higher education. Although the range of social diversification among the interviewees was significant and shows Jaskułowski's sensitivity to possible structural factors influencing attitudes towards migrants, it does not take into account possible differences between the three partition areas or between the centre and borderlands. The book will not tell us much about the attitudes towards migrants of Polish citizens who feel Silesian or Kashubian first and foremost, and only then - if at all - Polish. Jaskułowski leaves reflection about the historical and cultural determinants of attitudes to migrants to other scholars and focuses instead on Polishness as a hegemonic identity.

The Everyday Politics of Migration Crisis in Poland has a very clear structure. Its short chapters, containing clearly formulated topics, can be read separately. The first two chapters are an introduction to the study; they explain its aims, methods, and theoretical perspective. A reader who has considered in some depth the questions about the relation between national identity and current political discourse appearing in the book's first pages will not be surprised when Jaskułowski presents himself as a constructivist. He does not support the notion of a nation as a real community with a relatively unchanging identity, and he calls for the study of those practices and discourses that cause the leading category of political thinking to be the 
nation, with the recreation of old boundaries or the establishment of new ones between "us" and "them" (16). His aim is not to improve upon the constructivist paradigm but rather to make use of it in his empirical analysis, which appears in the succeeding chapters and is the most interesting part of the book.

The book's target audience is probably English-speaking, non-Polish scholars, and thus some explanations may seem unnecessary from a Polish point of view, while others may seem insufficiently developed. This is especially true of Chapter 3, where apart from discussing the EU's migration policy and the decisions of various Polish governments in this sphere (decisions well known to the Polish reader), there are several observations on the connection between Islamophobia and nationalist rhetoric in the rightwing political discourse and popular culture (and here the Polish reader will likely find the choice of cultural texts too narrow). Nevertheless, it is worthwhile for researchers familiar with the subject to read this chapter carefully, given the above-mentioned redefinition of the "European migration crisis" as a period of consent for the violation of migrants" rights.

As I was reading the third chapter, I also stopped to consider the notion of the "pathological Europeanisation" of the Polish discourse. "In other words," Jaskułowski writes,

in Western European countries, migration has become a central element of public discourse in Poland. Yet PiS have adopted the rhetoric typical of far-right nationalist parties in Western Europe. Thus, the party not only drew public attention to migration and linked migration issues to national security but also identified migrants and refugees with Muslims who had become the target of racial othering. The party mainstreamed and normalized both cultural and biological racism in the public sphere (38).

Yet the term proposed by Jaskułowski suggests that it was not parochialism but participation in the international discourse that made it easier for many Poles to link belief in their own superiority, fear of migrants, racism, and prejudice against Muslims, into an inseparable whole.

Various "-isations" usually entail some form of judgment about power, and thus also of responsibility for the effects of the processes they describe. "Colonisation," for example, signifies imposed power and assigns appropriate political responsibility to the colonisers. "Modernisation," on the other hand, is - at least in the social sciences - an example of fatalism describ- 
ing the domination of social and market processes over political authority. I wonder what vision of subjectivity lies behind the concept proposed by Jaskułowski. From an empirical perspective, "pathological Europeanisation" describes the fact that we emulated the European debate, although we did not have to face the challenge of rising migration in practice. At the same time - let the more neutral readers forgive this overt assessment - we were most fervent in welcoming the most loathsome elements of the debate. I am not entirely certain, however, how Jaskułowski understands the agency of the participants in the Polish discourse - whether they were Europeanised, whether they Europeanised themselves on their own, or whether Europeanisation describes some form of inertia in the social process. This is a difficult question because it concerns power and responsibility. It cannot be avoided, though, in studying prejudices, those peculiar structures of the common mindset in which automatic judgment meets political cruelty. Another question that arises in confrontation with "pathological Europeanisation" is what form correct Europeanisation should take.

From the perspective of the Polish reader, perhaps the most interesting element of the book is the report on the results of field research. In short, focused chapters, Jaskułowski discusses how the respondents understand their Polishness, and three different attitudes - hostile, solidary, or ambivalent - they displayed towards refugees from North Africa and the Middle East. There is no point in dwelling on Jaskułowski's observations of a very general nature, namely, that the sense of Polishness of the majority of the respondents was strong, that they had an unquestioning view of history, and that their mostly hostile attitude towards refugees was supported by Islamophobia. The author notes these facts with regret, but - in the understanding tradition of the social sciences - he analyses statements with which he does not agree and those with which, as ordinary human beliefs, he finds it easier to identify. More importantly, he senses a real tension in the shaping of opinions: if in the thicket of discursive practice an individual has some form of agency (and thus power and responsibility), it will find expression in this situation.

In Jaskułowski's analysis, the public discourse neither thinks nor speaks for the individual. It is rather material from which we derive opinions and meandering argumentation. Like any material, it also has its limitations. Thoughts can be expressed within the discourse, but this is done using what has already been said and in response to questions that have already been raised. Jaskułowski's respondents were in exactly this situation - irrespective of whether they were asked about Polishness or about 
the relocation of refugees, they stepped on the shaky ground of subjects that are constantly being discussed. It was not so much that they might draw on clichés as that they could not avoid drawing on them and still have something to say. In the respondents' emotionally charged responses, in their doubts or unwillingness to take a position, or in their attempts to question or renegociate the main categories of the public discourse, it was clear that the domination of those categories was uncomfortable. The respondents whose attitude Jaskułowski described as ambivalent - those who fluctuated between fear and the solidarity impulse - were especially uncomfortable with the categories. Respondents from this group spoke of their ignorance and fear of taking a stand. Some were suspicious of media reports. Others said they needed more time to arrive at a sensible opinion. Still others formulated conditional opinions, trying to position themselves on both sides of the argument at the same time. They did not want either to speak in clichés or firmly to oppose them. When reading the statements of respondents from this group, it is difficult not to get the impression that instead of going beyond the hegemonic language their dialectic quietly replicates it, because more abdication is involved than opposition (113-126).

Jaskułowski emphasises that people are not just passive recipients of the hegemonic discourse (129). His analysis certainly serves to consolidate this view, though it might have been even more interesting if he had considered the critical potential of the recipients' "activeness." A careful reader of his book will probably reflect on this question - because what good is it that people form their opinions autonomously, when in the end the opinions of the majority are not at variance with those that resound the loudest in the public sphere? Is the individualisation of their voices an aesthetic effect or an expression of ethical exploration? If I could commission one more chapter from the author, it would deal with this very issue, which incidentally is just another version of the question about power and responsibility.

Jaskułowski can be praised for many other things. Both the constructivist perspective and his assumption about the relation between attitudes towards migrants and national identity are corroborated in his analysis. Neither allows for the disregard of discussion in the media as a form of exercising power or of everyday thinking as a counter to statements in public circulation. The clarity of Jaskułowski's analyses, which are usually conducted separately at the level of identity, views, and the logic behind their justification, makes the book useful even for researchers who do not fully agree with his approach. Last but not least, the critical perspective adopted 
at the beginning of the work - which assumes the subjectivity of migrants as members of the European political community who are entitled to specific rights - is consistent with the further argumentation and also opens the way for reflection upon the "migration crisis" as a manifestation of a deeper crisis in the normative power of legal regulations (Legendre 2011).

The Everyday Politics of Migration Crisis in Poland also has some weak points. Personally, I consider one such drawback to be the lack of reference to the situation of refugees in Poland. Jaskułowski writes of them only that

[a]s we have seen, Poland was neither a destination for refugees [Jaskułowski writes "refugees," and not "refugees from the MENA countries" or "the refugees"] nor a transit country. In 2015, for instance, 12,325 applications for refugee status were submitted in Poland. Refugee status was granted to 348 persons, including 203 Syrians and 24 Iraqis (39). ${ }^{1}$

I suppose the author is simply trying to say in this fragment that in the period covered in the study Poland did not experience a rise in forced migration, and refugees from North Africa and the Middle East (i.e., the group in which Jaskułowski is most interested) rarely arrived here. Jaskułowski states, however, that no refugee route led through Poland, and such a statement can be countered by the very statistics he quotes. These figures indicate that in 2015, 12,000 people sought haven in Poland. Admittedly, some were returned to Poland from other countries under the Dublin Regulation; thus their escape route, mostly against their will, did indeed lead through Poland.

Statistics from the last decade show that every year a few thousand to a dozen thousand people apply for international protection in Poland. They mostly come from the former Soviet republics. They apply for protection despite the fact that Poland grants it to very few applicants and does not offer any real institutional support to asylum-seekers. ${ }^{2}$ Sociological suspi-

\footnotetext{
1 The manner of presenting the data in this portion of the book could easily lead to a misunderstanding, namely, it might be assumed that in 2016 the status was given to those people who applied for it in the same year. This is not the case: the status was received also by those who had applied for it in previous years. Considering the long-term and often multi-stage nature of the proceedings connected with granting international protection or other forms of legalising a stay, a proper presentation of the data should contain information as to whether decisions on applications were made in the same year.

${ }^{2}$ Polish refugee policy includes elements such as the prohibition to perform gainful employment for at least half a year after submitting an application, with very low benefits for persons subject to the procedure and possible detention of the entire family. Researchers also point to poor conditions
} 
ciousness leads one to wonder whether the Polish authorities are truly implementing the idea of international protection and putting the welfare of people seeking protection first, or whether they are pursuing some bureaucratic interest (such as the number of places available in refugee centres, the budget connected with material assistance for refugees, or the integration programme). Suspicion is also justified by the corroborated reports of violations of refugee rights at Polish border crossings. The first such signs surfaced at the end of 2016. The Border Guard at the Terespol border crossing began to make it impossible for migrants to apply for refugee status. This practice, which is not only illegal but also endangers human life, has persisted despite complaints, petitions, and court proceedings. It has been thoroughly documented by the press and NGOs. The European Court of Justice and the the Polish Ombudsman (Bodnar 2018) have also examined complaints in the matter. These Border Guard practices have most likely contributed to a threefold decrease in the number of applications for refugee status in the last three years. ${ }^{3}$ The Polish escape route from persecution, which was narrow but of long standing, may disappear from the European map (Klaus 2017).

Perhaps I expose myself to the charge of being over-meticulous in observing that a scholar who deals with migration on a many times greater scale has ignored the probable rights violations of, say, several thousand forced migrants. After all, the omission does not affect the main theses or results of the study. It does not undermine the value of the book and, in the context of the entire argument, looks more like an oversight than a profoundly considered element. There are three sentences, though, that allow the abuse of forced migrants in Poland, and on Poland's eastern border, to be downplayed. These three sentences do a great disservice to a cause for which Jaskułowski is the spokesman, namely, the respect of refugees' rights in Europe, including in Poland. After all, if there are no refugees in our country, then in principle no one is violating their rights.

Transl. Michelle Granas

in refugee centres, protracted bureaucratic procedures, and insignificant assistance in the integration process (Gracz \& Chrzanowska 2007; Górny 2017; Mikulska \& Patzer 2012).

${ }^{3}$ From 12,300 in 2015 and 2016 to 4,100 in 2018 (source: UDSC; yearly statistical reports concerning the international protection procedure in Poland are published by the Foreigners' Office (UDSC) and available online at: https://udsc.gov.pl/statystyki/raporty-okresowe/raport-roczny-ochrona-miedzynarodowa/). 
Bibliography:

/// Bodnar A. 2018. "Wystapienie do MSWiA w sprawie składania wniosków o status uchodźcy z 2018.09.24" [Address to the Ministry of the Interior and Administration about the submission of applications for refugee status from 24 September 2018].

/// Górczyńska M., Szczepanik M. 2016. Droga donikad. Relacja z wizyty monitoringowej na biatorusko-polskim przejściu granicznym Brzesść-Terespol, Helsińska Fundacja Praw Człowieka.

/// Górny A., ed. 2017. Uchodźcy w Polsce. Sytuacja prawna, skala naptywu i integracja w społeczeństwie polskim oraz rekomendacje, Komitet Badań nad Migracjami PAN.

/// Gracz K., Chrzanowska A. 2007. Uchodźcy w Polsce. Kulturowo-prawne bariery w procesie adaptacji, Stowarzyszenie Interwencji Prawnej.

/// Gutkowska A., ed. 2007. Uchodźcy w Polsce. Kulturowo-prawne bariery w procesie adaptacji, Stowarzyszenie Interwencji Prawnej.

/// Jaskułowski K. 2019. The Everyday Politics of Migration Crisis in Poland: Between Nationalism, Fear and Empathy, Palgrave Macmillan.

/// Klaus W. 2017. "Closing Gates to Refugees: The Causes and Effects of the 2015 'Migration Crisis' on Border Management in Hungary and Poland," Yearbook of the Institute of East-Central Europe, vol. 15(3), pp. 11-34.

/// Legendre P. 2011. Zbrodnia kaprala Lortiego. Traktat o Ojcu, transl. A. Dwult, Fundacja Augusta hr. Cieszkowskiego.

/// Mikulska A., Patzer H. 2012. Bieg przezptotki. Bariery na drodze integracji migrantów w Polsce, Helsińska Fundacja Praw Człowieka.

/// Dominika Michalak - defended her PhD thesis in sociology at the University of Warsaw in 2017. Her academic interests cover language and knowledge in the contexts of power relations and socio-cultural differences. She is currently working on a project regarding the language-related aspects of stay legalisation and international protection procedures for foreigners in Poland.

ORCID: https://orcid.org/0000-0001-7650-2750

Email:domichalak@gmail.com 